\title{
OPINIONS AND ATTITUDES OF CONSUMERS RELATED TO THE PURCHASE OF POTATOES AND REPERCUSSION ON THE OFFER OF FRENCH CULTIVARS
}

\author{
RITA DE CÁSSIA RIBEIRO* \\ HELENA MARIA PINHEIRO SANT'ANA** \\ JOAQUIM GONÇALVES DE PÁDUA $A^{\star \star \star}$ \\ JOSÉ BENICIO PAES CHAVES ${ }^{\star \star \star *}$
}

\begin{abstract}
The present work aimed to evaluate opinions and attitudes of consumers during purchase of potatoes, and analyze the availability of French cultivars. By means of focus groups, it was observed that the purchase of potatoes was affected by factors related to the potatoes themselves, such as size and shape, and environmental determinants. Decision making was based on previous experiences and cultural codes already established. Despite the importance of seals of quality, there was no significant indication that potato quality played a more important role than cultural patterns. It was concluded that even when offering specials on high quality cultivars, such as the French cultivar, special offers should be preceded by educational activities to establish cultural codes for the purchase of potatoes.
\end{abstract}

* Doutora em Ciência e Tecnologia de Alimentos, Professora Adjunta, Departamento de Nutrição, Universidade Federal de Minas Gerais, Belo Horizonte, MG, Brasil (e-mail: ritaribeiro@ufmg.br).

** Doutora em Ciência dos Alimentos, Professora Associada, Departamento de Nutrição, UFV Viçosa, MG, Brasil (e-mail: helena.santana@ufv.br).

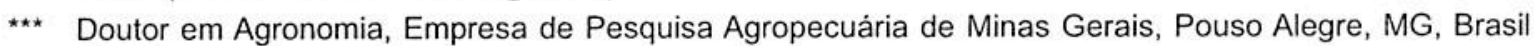
(e-mail: padua2008@gmail.com).

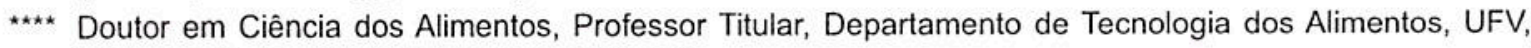
Viçosa, MG, Brasil (e-mail: jbchaves@ufv.br). 


\section{INTRODUCTION}

Potato plants (Solanum tuberosum, L.) produce tubercles with high nutritional value (NÚCLEO ..., 2006), and are among the most important and consumed foods in the world, after wheat, maize and rice (FAO, 2010).

Brazil is one of the largest producers of potatoes in South America and production reached 3.9 million tons in 2011 (FAO, 2013). The state of Minas Gerais is the largest national producer, demonstrating the economic relevance of the potato crop in this state for all those involved in the productive chain. However, problems related to sanitary quality, certification, traceability and organization of potatoes in the sector hinder production expansion and improvement.

In 1999, the Secretary of Agriculture, Livestock and Supply of the state of Minas Gerais established a technical cooperation program between Brazil and France with the objective of increasing the consumption of French potato cultivars in the state, organizing and modernizing the sector and improving marketing procedures. Many partners of the program have developed studies on biotechnology and adaptation of cultivars to the soil and climate of Minas Gerais. However, it is also necessary to understand the attitudes of consumers, since introduction of the French potato would change potato purchasing habits.

According to Contamine (2008), citizens of France purchase potatoes according to the culinary use desired, which directly affects the development and introduction of new cultivars in the country. This attitude is not observed in Brazil, which explains the importance of studying consumer behavior for adapting the French model for potato purchase in the capital of the state of Minas Gerais.

In traditional economic theory, consumer preferences determine the quantity and quality of product's attributes to be acquired. Consumers will select a combination that is in line with their budget constraints, since this reveals the maximum of goods or services that they can obtain. Among a multitude of choices, consumers select the one they prefer, which will maximize their satisfaction (SPERS, SAES \& SOUZA, 2004).

Authors such as Spers, Saes \& Souza (2004), Andreuccetti, Ferreira \& Tavares (2005), Henzs \& Reifschneider (2005) and Faria, Ferreira \& Garcia (2006) conducted studies in many locations of Brazil to understand the attitude of consumers regarding the purchase and use of different fresh vegetables. These authors concluded that product appearance (shape, size, color), packaging, price, health claims and cultural factors are crucial for consumer profiling.

The present study focuses on Brazilian public perception in relation to the quality of French potatoes. Common sense indicates a clear relationship of some potato characteristics with consumers, since the French varieties offer different possibilities, especially with respect to culinary uses. This is a distinctive quality which already functions in the French market and may also be suitable for the Brazilian market, ultimately allowing the consumer to obtain better culinary results.

The present work aimed to investigate the factors that affected the opinions and attitudes of consumers during purchase of potato and verify the possible effects on the promotion of French cultivars.

\section{MATERIAL AND METHODS}

A focus group is a qualitative method used to obtain information on the object of study. It is a set of people selected and gathered to discuss and comment a topic, based on their own personal experience (CALDER, 1977).

For Morgan (1997), focus group research aims to capture concepts, feelings, attitudes, beliefs, experiences and reactions, based on the information exchange carried out in the group, which would not be possible through other methods, such as observation, interviews or questionnaires. The 
focus group allows for many points of view and emotional processes to be known through interaction, thus favoring the capture of feelings little revealed by other methods. This qualitative technique can be employed in different contexts in the preliminary stages of research to support the construction of other investigation and hypotheses instruments, or verify trends. This technique can be later used to guide the planning of a large scale study with other data collection instruments (CALDER, 1977). The present study is an early step of consumer study in Belo Horizonte, Minas Gerais, Brazil.

The focus group technique has been a valuable tool for food studies when the product quality characteristics must be identified for consumers in stages preceding field research. Moreover, several studies have been carried out using qualitative research (BEHRENS et al., 2010; BARCELLOS et al., 2010; VERBEKE et al., 2010; LANDSTRÖN, HURSTI \& MAGNUSSON, 2009).

\subsection{PARTICIPANTS}

The focal groups were composed of people from three segments: those related to the Belo Horizonte Movement Housewife, housewives with no link to this movement, and former students of the Gastronomy program of the Faculdade Estácio de Sá (Belo Horizonte-Brazil). Participants of the focus group were recruited based on questionnaires sent to people of different segments. The individuals included in the research were those in charge of purchasing and preparation of horticultural products, including potatoes, for their household or at work. All were asked to fill out a questionnaire for characterization of their socioeconomic status and the data such as where and how often they purchased potatoes and how they are prepared.

Four consecutive focus groups were conducted, totaling 28 participants. Each focus group was composed of participants from the three different segments. It is emphasized that the participation of those related to the Belo Horizonte Housewife Movement was of great importance given the critical posture of these people in relation to consumer goods.

\subsection{PLANNING AND APPLICATION OF THE FOCUS GROUPS}

The focus groups were planned and conducted according to the methodology of Morgan (1997).

In this study, eight French potato cultivars, adequate for frying, baking and boiling were used, as well as the Agata cultivar (the most marketed in the state of Minas Gerais).

A technical description of the potatoes used in the study, according to information in the Catalogue Variétés de Pommes de Terre Produites en France (2009) is presented in Table 1.

\subsection{FIRST STAGE}

Agata and French potato cultivars were presented separately to the participants of the focus groups, identified with a label containing the name and recommended culinary use. The participants were allowed to ask questions about the different culinary uses and the origin of the potatoes. Next, they were informed and encouraged to organize themselves into pairs to prepare the potatoes according to the recommendations. Basic equipment and material, such as plates, tableware, knives for cutting and peeling, pans, strainers and ingredients (including whole milk, butter, soybean oil, salt, sausage and chive) were made available to the participants.

During approximately 90 minutes, the participants were allowed to handle, prepare and observe the sensory characteristics of the potato cultivars studied, including size, shape and appearance of the vegetables after they were peeled, cut, steam cooked and boiling, mashed, prepared for salads, baked and fried in vegetable oil.

Besides the preparation of different recipes using potatoes, the participants tasted and evaluated the sensory aspects of the foods prepared. They were also encouraged to share with the 
other participants their impressions regarding the sensory characteristics observed during preparation and tasting of the potatoes.

\section{TABLE 1 - PHYSICAL CHARACTERISTICS AND RECOMMENDED CULINARY USE OF THE POTATOES UTILIZED IN THE STUDY}

\begin{tabular}{|c|c|c|}
\hline Cultivar & Physical aspects of the potatoes & $\begin{array}{l}\text { Recommended culinary } \\
\text { use }\end{array}$ \\
\hline Agata & $\begin{array}{l}\text { Oblong, smooth and yellowish skin, yellowish-pallid pulp, with } \\
\text { fine texture and tendency for cracking during cooking }\end{array}$ & Boiling \\
\hline Bailla & $\begin{array}{l}\text { Short, yellowish skin and pulp, extremely fine texture and } \\
\text { resistant to disintegration during cooking }\end{array}$ & $\begin{array}{l}\text { Boiling / Prepared for } \\
\text { salad }\end{array}$ \\
\hline Canelle & $\begin{array}{l}\text { Oblong, smooth and yellowish skin, light yellow pulp, average } \\
\text { disintegration during cooking }\end{array}$ & Frying in vegetable oil \\
\hline Emeraude & $\begin{array}{l}\text { Oblong, regular, smooth and yellowish skin; yellowish pulp with } \\
\text { slightly gritty texture and little tendency to crack during cooking }\end{array}$ & $\begin{array}{l}\text { Boiling / Prepared for } \\
\text { mashed or baked }\end{array}$ \\
\hline Eole & $\begin{array}{l}\text { Oblong, very regular, smooth and yellow skin; yellowish pulp } \\
\text { with fine texture, tendency to crack during cooking }\end{array}$ & $\begin{array}{l}\text { Boiling / Prepared for } \\
\text { mashed or baked }\end{array}$ \\
\hline Florice & $\begin{array}{l}\text { Oblong, smooth and light yellow skin, light yellow pulp with fine } \\
\text { texture, and tendency to crack during cooking }\end{array}$ & $\begin{array}{l}\text { Boiling / Prepared for } \\
\text { mashed or baked }\end{array}$ \\
\hline Gredine & $\begin{array}{l}\text { Short, with predominance of small and medium sizes, smooth } \\
\text { and yellowish skin; yellow pulp with extremely fine texture and } \\
\text { resistance to cracking during cooking }\end{array}$ & $\begin{array}{l}\text { Boiling / Prepared for } \\
\text { salad }\end{array}$ \\
\hline Opaline & $\begin{array}{l}\text { Oblong, smooth and yellowish skin; yellowish-pallid pulp with } \\
\text { slightly gritty texture and little tendency for cracking during } \\
\text { cooking }\end{array}$ & Frying in vegetable oil \\
\hline Soleia & $\begin{array}{l}\text { Oblong, yellow skin, smooth or slightly rough; yellow pulp with } \\
\text { slightly gritty and dry pulp, presenting tendency for cracking } \\
\text { during cooking }\end{array}$ & Frying in vegetable oil \\
\hline
\end{tabular}

\subsection{SECOND STAGE}

After conclusion of the first stage, the participants were taken to the Laboratory of Journalism, where they gathered for discussion in the presence of a group moderator and an observer. The debates followed a script, which is presented in Table 2, and each focus group lasted about 60 minutes.

The discussions were recorded on video for later transcription. The transcriptions were evaluated in a software system specific for qualitative data analysis (ATLAS.ti, version 5.0).

For analysis of the data, sixteen codes were created to group the opinions of the participants according to the theme discussed for analysis of the data generated in the focus groups. Each code created was preceded by the abbreviations DC (housewives); MDC (housewives linked to the housewives movement of Belo Horizonte) and EA (former students of the Gastronomy program), which allowed intra and inter focus group analysis. Later, the sixteen codes were organized in seven families of codes, allowing the grouping of related items and analysis of the ideas presented. 
TABLE 2 - GUIDE FOR DISCUSSIONS IN THE FOCUS GROUPS REGARDING OPINIONS AND ATTITUDES OF CONSUMERS RELATED TO PURCHASE, PREPARATION AND CONSUMPTION OF POTATOES

\begin{tabular}{|c|c|}
\hline Themes & Items examined \\
\hline $\begin{array}{l}\text { Comparison between French potato cultivars and Agata } \\
\text { potatoes in different culinary preparations }\end{array}$ & $\begin{array}{l}\text { Facility of peeling and cutting, time of } \\
\text { cooking and general sensory aspects after } \\
\text { cooking }\end{array}$ \\
\hline Physical characteristics that affect potato purchase & $\begin{array}{l}\text { Size, aspects of the skin and presence of } \\
\text { sprouts and green parts }\end{array}$ \\
\hline Effect of erroneous information on the purchase of potato & Credibility and seal of quality \\
\hline $\begin{array}{l}\text { Effect of the recommended culinary use on the purchase of } \\
\text { potatoes }\end{array}$ & $\begin{array}{l}\text { Information on the name of cultivars and } \\
\text { specific culinary uses }\end{array}$ \\
\hline Effect of price on the purchase of potato & $\begin{array}{l}\text { Relation between cost, benefits, quality and } \\
\text { information about culinary use }\end{array}$ \\
\hline Effect of packaging on the purchase of potatoes & $\begin{array}{l}\text { Type and size of the packaging and } \\
\text { information contained in the labels }\end{array}$ \\
\hline Market segmentation and the purchase of potatoes & $\begin{array}{l}\text { Different types of markets for the } \\
\text { commercialization of French potatoes }\end{array}$ \\
\hline
\end{tabular}

\section{RESULTS AND DISCUSSION}

\subsection{SOCIOECONOMIC CHARACTERIZATION OF THE PARTICIPANTS OF THE FOCUS GROUPS, FREQUENCY OF PURCHASE AND FORMS OF POTATO CONSUMPTION}

Twenty-two $(78.6 \%)$ women and six $(21.4 \%)$ men participated of the study. Both the men and women were in charge of purchase and preparation of fruits and vegetables, including potato, in their household or workplace.

It is interesting to point out the participation of men in this research. Even today, it is natural to expect a higher number of female participants in this study since these activities are traditionally performed by women (purchase and preparation of meals). However, according to the data from the Brazilian Institute of Statistics and Geography (IBGE, 2008), women have presented changes in their social behavior. Reduced fertility, increasing participation of women in the labor market, contribution to family income and increased educational level are crucial aspects to their role in Brazilian society. Such aspects lead to the redistribution of domestic functions, without considering the professional cooks/chefs, represented in this study by former students of the Gastronomy program.

The presented data revealed that $3(10.7 \%)$ participants of the focus groups had between 20 and 29 years old; $2(7.1 \%)$ were 30 to $39 ; 6(21.4 \%)$ were 40 to $49 ; 10(35.5 \%)$ were 50 to $59 ; 5$ $(18.2 \%)$ were 60 to 69 ; and $2(7.1 \%)$ were 70 or older. However, most participants $(82.2 \% ; n=23)$ were 40 or older.

In relation to educational level, 1 person $(3.6 \%)$ had concluded only elementary school; 3 $(10.4 \%)$ had not finished elementary school; 5 (18.2\%) had graduated from high school; 15 (53.5\%) had graduated from college and $4(14.3 \%)$ declared to be attending college.

In relation to monthly family income, $5(18.2 \%)$ participants declared that their families received less than $R \$ 1.000,00$ (US\$ 555.00); 7 (25.0\%), between $R \$ 1.000,00$ and $R \$ 2.000,00$ (US $\$ 555.00$ to US $\$ 1 ; 110,00$ ) and $16(56.8 \%)$, more than R $\$ 2.000,00$ (US\$1.110,00).

The data related to location and frequency of potato purchase and preparation procedures are presented in Table 3. 
It can be observed that potatoes are frequently purchased in supermarkets and vegetable markets. Most participants purchase potatoes weekly, due to their perishability.

In relation to the frequency of consumption, it was observed that all participants consume potatoes at least once a week. It is interesting to point out that this is one of the staple foods of the participants in this study. The potato plays an important dietary role that contributes to the increased energy of meals for the Brazilian population. Frying was the most common culinary preparation. The participants in this study tend to consume fried food (BRASIL, 2006). However, a large number of participants preferred cooked or mashed potatoes, which deserves to be explored in the strategies for advertising new potato cultivars for these purposes. Besides, this is a healthier alternative for consuming this food.

TABLE 3 - INFORMATION PROVIDED BY THE PARTICIPANTS OF THE FOCUS REGARDING THE PURCHASE AND PREPARATION OF POTATOES IN BELO HORIZONTE (MINAS GERAIS - BRAZIL)

\begin{tabular}{|c|c|c|c|}
\hline & & $\mathrm{n}$ & $(\%)$ \\
\hline \multirow{3}{*}{ Location of purchase } & Supermarket & 12 & 42.9 \\
\hline & Sacolão & 14 & 50.0 \\
\hline & Central market of Belo Horizonte & 2 & 7.1 \\
\hline \multirow{3}{*}{$\begin{array}{l}\text { Frequency of } \\
\text { purchase }\end{array}$} & Weekly & 22 & 78.6 \\
\hline & Fortnightly & 6 & 21.4 \\
\hline & Monthly & 0 & 0.0 \\
\hline \multirow{5}{*}{$\begin{array}{l}\text { Frequency of } \\
\text { consumption }\end{array}$} & More than three times a week & 4 & 14.3 \\
\hline & Two to three times a week & 14 & 50.0 \\
\hline & Once a week & 10 & 35.7 \\
\hline & Once every two weeks & 0 & 0.0 \\
\hline & Once a month & 0 & 0.0 \\
\hline \multirow{5}{*}{$\begin{array}{l}\text { Most frequent culinary } \\
\text { preparation }\end{array}$} & Fried & 11 & 39.2 \\
\hline & Cooked & 10 & 35.7 \\
\hline & Mashed & 6 & 21.7 \\
\hline & Baked & 1 & 3.4 \\
\hline & Dumplings and croquettes & 0 & 0.0 \\
\hline
\end{tabular}

'In Brazil, sacolões are shops that sell mainly fresh fruits and vegetables.

\subsection{COMPARISON BETWEEN POTATOES OF THE FRENCH AND AGATA CULTIVARS IN DIFFERENT CULINARY PREPARATIONS}

The characteristics indicated by the participants in the study regarding preparation of the French potatoes were: fast cooking; firm texture when cut; dry aspect after cooking; facility of mixing the ingredients for mashed potatoes due to the texture of the French cultivars; crispness after frying and difficulties for handling potatoes suitable for salad due to their small size, which increases the time required for preparation.

When questioned about the difficulties in using the Agata potato, which is the most marketed cultivar, the participants highlighted slow and uneven cooking, dismemberment when being cut and moist appearance after cooking.

All participants of the focus groups reported high absorption of oil during frying, with decreased crispness of the Agata cultivar. Moreover, they demonstrated knowledge about better cultivars for this culinary purpose, such as the "purple skin" potato. The "purple skin" potato mentioned in this study is the Asterix cultivar, with red skin and considerable amount of dry matter, which makes it suitable for frying. However, it must be highlighted that not all cultivars with purple or red skin are suitable for frying. The characteristics presented by the Agata cultivar result from its chemical 
composition, including low content of dry matter (FELTRAN, LEMOS \& VIEITES, 2004; FINOTTI, BERTONE \& VIVANTI, 2006).

The participants made several preparations using the Agata cultivar, such as mashed, baked and fried potato and gnocchi, since no cultivars suitable for different culinary use are available and because they are already "used to" the results, i.e., habituated to the sensory characteristics provided by this cultivar.

The EA group mentioned the more pronounced and sweet flavor of the French cultivars, but there was little discussion about this sensory attribute among other participants of the focus groups.

According to Contamine (2008), the characteristics considered most important in the sensory evaluation of potato vary in different parts of the world. In Spain, consumers appreciate large potatoes, such as those of the Estima cultivar, to prepare them as entrees. In France, the flavor of potatoes is a priority. Thus, many cultivars have been developed to meet the different demands.

It can be observed that during the discussions in the focus groups, the participants in this research emphasized "appearance" as the most important sensory attribute in evaluation of the fresh potato, while the texture of the cooked or fried preparation was also pointed out. The perception of the different flavor was reported only by the EA group, possibly because the palate of those in this group is more refined due to their profession. This may indicate market segmentation because of the characteristics of different potato consumers.

\subsection{PHYSICAL CHARACTERISTICS THAT AFFECT THE PURCHASE OF POTATOES BY CONSUMERS}

At the moment of purchase, the decisive physical characteristics of potatoes were:

a) Size: the largest potatoes are more easily and quickly peeled and cut, mainly in the form of French fries. When the objective is to cook the whole potato with the skin, smaller tubercles are preferred. Consumers believe that the size of potatoes indicates quality, where small potatoes are of poorer quality. Therefore, many times they are thought to be cheapest for this reason;

b) Shape: oval and regular. Participants look for standardization of size and shape when purchasing;

c) Skin: smooth, light yellow, free from dirty or defects (sprouts and holes), without greenish areas.

Participants in the focus groups clearly expressed that physical characteristics of the potatoes play an important role in their acquisition. This topic could be further discussed, focusing on the information processing that occurs when making a decision to purchase a product or service.

Blackwell, Miniard \& Engel (2005) declared that the starting point of any purchase decision is identification of consumers' needs. Once this need is recognized, individuals start to seek information and solutions to meet this need. The search may be internal, by recovering knowledge from memory, or external, through the collection of information from peers, relatives and the market. In this sense, Ferreira (2007) explains that there is a mental sequence of steps in the selection process, starting from the perception and acquisition of information related to the existing alternatives, and comparison with past situations, either good or bad.

Thaler \& Sunstein (2008) report that two types of reasoning are used in the decision making process, the Automatic System and the Reflexive System. The first is fast, associative and instinctive; while the second is slower, intentional and conscious.

However, the Automatic System can be trained with much repetition and become involuntary. This can be noticed in different situations involving the purchase of foods. In the case of potatoes, the constant offer of the same cultivar leads consumers to establish standards for purchase and use. Based on this reasoning, Rapaille (2007) highlights the so-called cultural code, which forms an unconscious meaning applied to everything. The codes are established according to the cultural environment, which allows the same information to be processed in different ways, according to the local culture. 
It is possible to draw parallels between the findings of this study and French potato consumption. The explanation above suggests the existence of a common cultural code for the consumers described in this work. Size, shape and aspects most valued by the participants of the focus groups demonstrate that there may be a possible common unconscious significance with respect to potatoes' physical characteristics. This is an important issue that may be useful for new studies on Brazilian potato consumer practices.

In France, there is no association between quality and physical appearance of potatoes. Therefore, purchase is based on flavor and the desired culinary preparation, regardless of size, shape, thickness, color and aspect of the skin. The cultivars are adapted to the culinary demands of consumers, which creates a gastronomic segmentation. It indicates another common unconscious meaning for potato in that country and, as Rapaille (2007) declared, there was another cultural code.

\subsection{EFFECT OF ERRONEOUS INFORMATION ON THE PURCHASE OF POTATOES BY CONSUMERS}

Consumers seek for true information regarding the use and advantages of French potato cultivars. The MDC group hypothesized that marketers advertise the sale of a certain cultivar, but sell another instead, such as Agata, since the potatoes are somewhat alike. This would definitely have a negative effect on the promotion of French potatoes. Besides, irregular information on the product would lead consumers to reject these potatoes instead of use them.

It is necessary to certify the potato cultivars to assure the quality and regularity of correct information provided to clients. The presence of a quality seal clearly shows that the products were verified. Therefore, a quality seal may become an important marketing tool for well-informed consumers and those aware of the differences among potato varieties. It would be positively evaluated by consumers and minimize the risks of fraud as mentioned above.

The EA and MDC groups discussed the cultural aspects of potatoes consumption in Brazil. They pointed out that the habit of purchasing potatoes according to the specific culinary use is incipient and that people generally buy according to appearance. Larger potatoes are preferred, with smooth, clear and clean skin, and free of visible defects. It was again stressed the need for educational campaigns on the purchase and use of these potatoes.

It is interesting that the participants in this work, the former students of the Gastronomy program and the housewives associated to the housewife movement, indicated that they purchased potatoes according to appearance and that this behavior would not change unless they received sufficient and adequate information. Thus, the information provided to consumers should include the type of cultivar, origin, recommended culinary use, preparation tips, recipes and, especially, information on the culinary quality of French potato cultivars.

\subsection{THE EFFECT OF INFORMATION REGARDING THE RECOMMENDED CULINARY USE ON THE PURCHASE OF POTATOES}

The identification of the cultivars by their names and culinary use was considered an interesting procedure. Some of the comments were: "it would be sensational", "I think it will be a success", "I find it cool". On the other hand, participants pointed out that the identification of the cultivar alone would not be sufficient. A set of information and explanations on culinary use, sensory aspects and low prices are crucial to promote French cultivars.

Especially in the case of the EA group, it seems that if consumers obtain information about the potatoes they are buying, they will choose the best product for culinary use, regardless of appearance. It was stated that if "those ugly potatoes" were best for salads, they would buy them. Besides, since the best cultivars for fried and mashed potato were somewhat similar (size and shape) to Agata, they would not be able to distinguish them without proper identification, as observed in their statements: "there may be several types there, but if they do not have a specific name, people 
will think they are the same", "these potatoes will only be purchased if the name is written, never due to appearance".

Besides the sensory aspects it is important to point out other factors that undermine purchase and use of potatoes. These extrinsic factors are as important as the sensory attributes, also called intrinsic factors (appearance, smell, flavor and texture). This study demonstrated the effect of information on the process of promoting French potato cultivars. Information on the recommended culinary use contributed to dissociate the culinary quality of potatoes from their appearance.

Other studies have demonstrated the importance of intrinsic and extrinsic attributes, including brand, information on labels, quality seal and price that affect directly consumer's decision making.

In a study on the acceptability of cured hams in Spain, Resano, Sanjuán \& Albisu (2007) have observed that the information regarding the region of origin of the products affected positively its acceptance, surpassing other information that are traditionally provided. Enneking, Neumann \& Henneberg (2007) studied the degree of influence of price, label and reduced sugar on the selection of carbonated orange-flavored beverages. The authors concluded that it is not sufficient to determine only the factors that affect selection by the consumers, but it is important to evaluate the interaction between intrinsic and extrinsic factors in this process. On the other hand, determination of these factors is directly related to cultural aspects. The intrinsic and extrinsic factors that determined the selection of potatoes by the participants in the present study are probably different from the factors that motivate consumers in France, the country of origin of the cultivars analyzed in this study.

The study performed by Prescott et al. (2002) illustrates this very well. These authors ranked nine factors that determine the selection of food in Japan, New Zealand, Taiwan and Malaysia. While the Japanese population prioritized price, and secondly, information on health and absence of additives, in New Zealand, the sensory aspects of food are prioritized, followed by price and health information.

Regarding quality seals, it is known that these are visible forms of demonstrating that products have been verified and present differentiated quality attributes. However, many consumers may not know the real meaning of a seal as shown in the study by Faria et al. (2006). Many rely on this imaging as a synonym for quality. Perhaps the visual appeal of the seals denotes quality, even without the consumer fully understanding its meaning.

In a study performed by Carpenter \& Larceneux (2008) on the effectiveness of quality seals in France, the authors concluded that it is necessary to explain to consumers the meaning of the seals in order to contribute to the construction of views on quality. Thus, one can say that the visual representation of quality seals is already a positive factor in the acquisition of potatoes; however, this representation should be summed with information on its meaning and importance. This suggests that it is necessary to investigate the extrinsic and intrinsic agents that affect the choices of consumers from Minas Gerais concerning the purchase of potatoes, mainly when dealing with foreign cultivars.

\subsection{THE EFFECT OF PRICE ON THE PURCHASE OF POTATOES BY CONSUMERS}

When asked about the possibility of buying French cultivars at a higher cost, the DC group was unanimous in asserting that they would not pay more for the French potatoes, but they agreed that for those genuinely concerned about culinary use, there would be no problem in spending a little more money. The MDC group declared the same, but they also said that if they knew about the use and advantages of the French cultivars, they would evaluate the cost-benefit ratio. This issue was corroborated by the EA group, which would pay a little more (few cents) for a cultivar that offers a better culinary result. Information on cultivars, their specific uses and advantages would be crucial in this process.

In the second stage of the consumer purchasing process described by Blackwell, Miniard \& Engel (2005), there is a search for information regarding the product. The extent of this search is determined by variables such as social class, personality, income, size of the purchase, past experiences and satisfaction of consumers. In this stage, as consumers are exposed to information (written materials at points of sale, folders, internet sites), they begin to process the stimulus, which 
involves attention, understanding, acceptance and retention. It is expected that the new information will be accepted and remain in the memory so that it is available in future occasions. In the evaluation of pre-purchase alternatives, consumers will evaluate the options identified during the previous stage, which may lead to purchase. This reveals that exposing consumers to information favors the selection process. The participants of the focus groups reported that if they had previously known the qualities of French cultivars during culinary preparation, they would have purchased them regardless of their physical characteristics. Size, shape and aspects of the skin would not determine the purchase of potato, and the Reflexive System would favor a conscious selection, according to the studies of Thaler \& Sunstein (2008).

The price of the potatoes seemed to be an important factor at the time of purchase, mainly for the DC group. Blackwell, Miniard \& Engel (2005) reported that when consumers have access to more information about the quality of the products, they are less sensitive to price and tend to purchase products of better quality. This corroborates the need for providing information for consumers about the uses and characteristics of the different types of potatoes studied.

\subsection{EFFECT OF PACKAGING ON THE PURCHASE OF POTATOES BY CONSUMERS}

It was observed that individuals preferred to select potatoes one by one, which would not be possible if potatoes were marketed pre-packaged. When they are packaged, consumers prefer packagings that allow the visualization of the product, via the use of nets or transparent plastic. The presence of a label with information about the product would be indispensable, mainly presenting recommendation for specific culinary uses. Packagings with capacity for 1 to $2 \mathrm{~kg}$ would be the most appropriate. One of the advantages of using packagings, besides convenience and speed at the time of purchase, would be the separation of cultivars, thus preventing that various potato varieties are mixed which is often observed in vegetable markets and supermarkets.

Other Brazilian authors identified factors that determine the purchase of other products of plant origin, such as "mandioquinha" (Arracacia xanthorrhiza), tomato, pineapple and banana (MATSUURA, COSTA \& FOLEGATTI 2004; HENZ \& REIFSCHNEIDER, 2005; ANDREUCCETTI, FERREIRA \& TAVARES 2005; MIGUEL et al., 2007). The visualization of food has great effect on decision making at the time of purchase, since standards related to the appearance of foods have already been established.

\subsection{MARKET SEGMENTATION AND THE PURCHASE OF POTATOES BY CONSUMERS}

The need for market segmentation was also observed, which was mainly discussed by the EA group. These individuals believe that initially the impact of domestic use of the French potato cultivar will not be as striking as it will be on the commercial scale. These reports suggest a probable segmentation of the market for potatoes with different culinary use. It must be highlighted that most potatoes are marketed in Brazil for domestic use. However, there is increased industrialization of these potatoes, mainly in the production of frozen pre-fried potato chips and snacks. Restaurants, bars, cafeterias, etc. were mentioned by the participants of the focus groups as another commercial segment.

The number of bars and restaurants in Brazil has increased, mainly in large urban centers, due to demand of the population to eat out. This behavior has significantly affected the food structure of different societies, regardless of their degree of development.

In France, the country of origin of the cultivars analyzed in this research, with solid and traditional eating habits, Michaud et al. (2002) discussed the trend of simplification of meals. In Brazil, studies on family budgets (Pesquisas de Orçamentos Familiares) (IBGE, 2010) reveal a change in the standards of food consumption in households, giving rise to the food and nutrition transition discussed by Coutinho, Gentil \& Toral (2008). In this sense, factors such as the entrance of women into the labor market, development of the food industry, the distance between the workplace and households, convenience and lack of time for meals contribute to the emergence of self-service fast 
food restaurants and snack bars. These environments may be an interesting niche market for the promotion of French potato cultivars. Further studies on this subject are necessary for more information.

\section{CONCLUSION}

The results of this study have led to the conclusion that there is a cultural code mainly related to the appearance of fresh potatoes, such as size, shape and aspects of the skin. This code interferes in the perception of qualitative objectives, such as well-defined culinary use.

Discussions in the focus groups revealed that the participants were satisfied with the results achieved with the use of French potato cultivars. Access to information regarding the culinary quality of each cultivar contributed decisively to separate physical aspect of tubercles from the results obtained during preparation.

Therefore, the quality factors that affected the purchase and use of potatoes were size, shape and color; texture of the skin; presence or absence of dirt, defects and green areas; information on the culinary use, type and origin of the cultivar; and presence or absence of packagings. Regarding price, the data suggest market segmentation, since the studied groups differed in relation to household incomes.

Quality seals are important in this process, but are not more important than habits, tastes and emotions of the consumers. After all, besides indicating quality, setting standards and committing to compliance, researchers can and should question what quality means to consumers.

Finally, the behavior of the Brazilian potato consumers is different from the standards established in France, for example. Therefore, in the process of promoting French cultivars some issues must be considered, including availability of information about culinary use and the disassociation of potato physical aspects from their sensory quality.

\section{RESUMO}

\section{OPINIÖES E ATITUDES DOS CONSUMIDORES EM RELAÇÄO À COMPRA DE BATATAS E REPERCUSSÃO NA OFERTA DE CULTIVARES FRANCESAS}

Este trabalho teve por objetivo avaliar as opiniões e as atitudes dos consumidores sobre a aquisição de batatas e analisar sua repercussäo na oferta de cultivares francesas. Por meio de grupos de foco, verificou-se que a compra de batatas era influenciada por fatores relacionados aos próprios tubérculos como, tamanho e formato, bem como por determinantes ambientais. A tomada de decisão concretizava-se a partir de experiências anteriores e códigos culturais já estabelecidos. Concluiu-se que a promoçäo de cultivares francesas deverá ser precedida por ações educativas de forma a estabelecer outro código cultural para compra de batatas.

PALAVRAS-CHAVE: BATATA; COMPORTAMENTO DO CONSUMIDOR; GRUPO DE FOCO.

\section{REFERENCES}

1 ANDREUCCETTI, C.; FERREIRA, M. D.; TAVARES, M. Perfil dos compradores de tomate de mesa em supermercados da região de Campinas. Horticultura Brasileira, v. 23, p. 148-153, 2005.

2 BARCELLOS, M. D.; KÜGLER, J. O.; GRUNERT, K. G.; VAN WEZEMAEL, L.; PÉREZ-CUETO, F. J. A.; UELAND, O.; VERBEKE, W. European consumers' acceptance of beef processing technologies: a focus group study. Innovative Food Science and Emerging Technologies, v. 11, p. 721-732, 2010.

3 BEHRENS, J. H.; BARCELLOS, M. N.; FREWER, L. J.; NUNES, T. P.; FRANCO, B. D. G. M.; DESTRO, M. T.; LANDGRAF, M. Consumer purchase habits and views on food safety: a Brazilian study. Food Control, v. 21, p. 963-969, 2010.

4 BLACKWELL, R. D.; MINIARD, P. W.; ENGEL, J. F. Comportamento do consumidor. 9. ed. São Paulo: Pioneira Thomson Learning, 2005.

5 BRASIL. Ministério da Saúde. Guia alimentar para a população brasileira: promovendo a alimentaçāo saudável. Brasilia, 2006.

6 CALDER, B. J. Focus groups and the nature of qualitative marketing research. Journal of Marketing Research, v. 16, p. 353-364, 1977. 
7 CARPENTER, M.; LARCENEUX, F. Label equity and the effectiveness of values-based labels: an experiment with two French Protect Geographic Indication labels. International Journal of Consumer Studies, v. 32, p. 499-507, 2008.

8 CATALOGUE Variétés de Pommes de Terre produites en France. Paris: FNPPPT, 2009.

9 CONTAMINE,A. C. Marchés de la pomme de terre dansI'Union européenne. Cahiers Agricultures, v. 17, p. 335-342, 2008.

10 COUTINHO, J. G.; GENTIL, P. C.; TORAL, N. A desnutrição e obesidade no Brasil: o enfrentamento com base na agenda única da nutrição. Cadernos de Saúde Pública, v. 24, p. 332-340, 2008.

11 ENNEKING, U.; NEUMANN, C.; HENNEBERG, S. How important intrinsic and extrinsic product attributes affect purchase decision. Food Quality and Preference, v. 18, p. 133-138, 2007.

12 FARIA, I. G.; FERREIRA, J. M; GARCIA, S. K. Mercado consumidor de carne suina e derivados em Belo Horizonte. Arquivo Brasileiro de Medicina Veterinária e Zootecnia, v. 58, p. 251-256, 2006.

13 FAO. Food and Agriculture Organization of the United Nations. FAOSTAT. Available on: <http://faostat.fao.org/site/339/ default.aspx. Accessed at: 20 May 2013.

14 FELTRAN, J. C.; LEMOS, L. B.; VIEITES, R. L. Technological quality and utilization of potato tubers. Science Agriculture, v. 61, p. $598-603,2004$.

15 FERREIRA, V. R. M. Informações econômicas e ilusão: uma contribuição psicanalitica ao estudo de fenômenos econômicos. Ágora, v. 10, n. 107-126, 2007.

16 FINOTTI, E.; BERTONE, A.; VIVANTI, V. Balance between nutrients and anti-nutrients in nine Italian potato cultivars. Food Chemistry, v. 99, p. 698-701, 2006.

17 HENZ, G. P.; REIFSCHNEIDER, F. J. B. Formas de apresentação e embalagens de mandioquinha salsa no varejo brasileiro. Horticultura Brasileira, v. 23, p. 61-67, 2005.

18 IBGE. Instituto Brasileiro de Geografia e Estatistica. Coordenação de Índices de Preço. Pesquisa de orçamentos familiares, 2008-2009: avaliaçäo nutricional da disponibilidade domiciliar de alimentos no Brasil. Rio de Janeiro, 2010.

19 IBGE. Instituto Brasileiro de Geografia e Estatística. Diretoria de Pesquisas. Coordenação de População e Indicadores Sociais. Sintese de indicadores sociais: uma análise das condiçōes de vida da população brasileira. Rio de Janeiro, 2008.

20 LANDSTRÖN, E.; HURSTI, U. K. K.; MAGNUSSON, M. Functional foods compensate for an unhealthy lifestyle. Some Swedish consumers' impressions and perceived need of functional foods. Appetite, v. 53, p. 34-43, 2009.

21 MATSUURA, F. C. A. U.; COSTA, J. I. P.; FOLEGATTI, M. I. S. Marketing de banana: preferência do consumidor quanto aos atributos de qualidade dos frutos. Revista Brasileira de Fruticultura, v. 26, p. 48-52, 2004.

22 MICHAUD, C.; BAUDIER, F.; GUILBERT, P.; CAREL, D.; LE BIHAN, G.; GAUTIER, A.; DELAMAIRE, C. Les repas de français: resultats du baromètre santé nutrition. Cahiers de Nutrition et de Diététique, v. 39, p. 203-209, 2002.

23 MIGUEL, A. C. A.; SPOTO, M. H. F.; ABRAHĀO, C.; SILVA, P. P. M. Aplicação do método QFD na avaliação do perfil do consumidor de abacaxi "Pérola". Ciência e Agrotecnologia, v. 31, p. 563-569, 2007.

24 MORGAN, D. L. Focus groups as qualitative research. $2^{\text {nd }}$ ed. London: Sage Publications, 1997.

25 NÚCLEO DE ESTUDOS E PESQUISA EM ALIMENTAÇÃO. Tabela brasileira de composição de alimentos. Campinas, SP: NEPA-UNICAMP, 2006.

26 PRESCOTT, J.; YOUNG, O.; O'NEILL, L.; YAU, N. J. N.; STEVENS, R. Motives for food choice: a comparison of consumers from Japan, Taiwan, Malaysia and New Zealand. Food Quality and Preference, v. 13, p. 489-495, 2002.

27 RAPAILLE, C. O código cultural: por que somos tão diferentes na forma de viver, comprar e amar? Rio de Janeiro: Elsevier, 2007.

28 RESANO, H.; SANJUÁN, A. I.; ALBISU, L. M. Consumers' acceptability of cured ham in Spain and the influence of information. Food Quality and Preference, v. 18, p. 1064-1076, 2007.

29 SPERS, E. E.; SAES, M. S. M.; SOUZA, M. C. M. Análise das preferências do consumidor brasileiro de café: um estudo exploratório dos mercados de São Paulo e Belo Horizonte. Revista de Administração da Universidade de São Paulo, v. 39, p. $53-61,2004$.

30 THALER, R. H.; SUNSTEIN, C. R. Nudge: improving decisions about health, wealth, and happiness. New Haven: Yale University Press, 2008.

31 VERBEKE, W. et al. European beef consumers' interest in a beef eating-quality guarantee insights from a qualitative study in four EU countries. Appetite, v. 54, p. 289-296, 2010. 